\title{
Adult Neural Stem Cell Migration Is Impaired in a Mouse Model of Alzheimer's Disease
}

\author{
Daniel Esteve ${ }^{1,2} \cdot$ María Micaela Molina-Navarro ${ }^{3}$ Esther Giraldo ${ }^{4,5} \cdot$ Noelia Martínez-Varea $^{6,7}$. \\ Mari-Carmen Blanco-Gandia ${ }^{8} \cdot$ Marta Rodríguez-Arias $^{8} \cdot$ José Manuel García-Verdugo $^{3} \cdot$ José Viña $^{1,2} \cdot$ Ana Lloret $^{1,2}$ (1)
}

Received: 17 August 2021 / Accepted: 26 October 2021 / Published online: 11 December 2021

(c) The Author(s) 2021

\begin{abstract}
Neurogenesis in the adult brain takes place in two neurogenic niches: the ventricular-subventricular zone (V-SVZ) and the subgranular zone. After differentiation, neural precursor cells (neuroblasts) have to move to an adequate position, a process known as neuronal migration. Some studies show that in Alzheimer's disease, the adult neurogenesis is impaired. Our main aim was to investigate some proteins involved both in the physiopathology of Alzheimer's disease and in the neuronal migration process using the APP/PS1 Alzheimer's mouse model. Progenitor migrating cells are accumulated in the V-SVZ of the APP/PS1 mice. Furthermore, we find an increase of Cdh1 levels and a decrease of Cdk5/p35 and cyclin B1, indicating that these cells have an alteration of the cell cycle, which triggers a senescence state. We find less cells in the rostral migratory stream and less mature neurons in the olfactory bulbs from APP/PS1 mice, leading to an impaired odour discriminatory ability compared with WT mice. Alzheimer's disease mice present a deficit in cell migration from V-SVZ due to a senescent phenotype. Therefore, these results can contribute to a new approach of Alzheimer's based on senolytic compounds or pro-neurogenic factors.
\end{abstract}

Keywords Subventricular zone $\cdot$ Beta-amyloid toxicity $\cdot$ Neurogenesis $\cdot$ Senescence $\cdot$ Olfaction

\begin{tabular}{llll}
\multicolumn{2}{l}{ Abbreviations } & APP & Amyloid precursor protein \\
$\mathrm{A} \beta$ & $\beta$-Amyloid & ATM & Ataxia telangiectasia mutated \\
$\mathrm{AD}$ & Alzheimer's disease & b-Gal & B-galactosidase \\
APC/C & Anaphase-promoting complex & Cdh1 & CDC20 homologue 1
\end{tabular}

José Viña

jose.vina@uv.es

Ana Lloret

ana.1loret@uv.es

Daniel Esteve

Daniel.esteve@ext.uv.es

María Micaela Molina-Navarro

m.micaela.molina@uv.es

Esther Giraldo

egiraldo@cipf.es

Noelia Martínez-Varea

noeliafisioneuro@gmail.com

Mari-Carmen Blanco-Gandia

m.carmen.blanco@uv.es

Marta Rodríguez-Arias

Marta.Rodriguez@uv.es

José Manuel García-Verdugo

j.manuel.garcia@uv.es
1 Freshage Research Group, Department of Physiology, Faculty of Medicine, University of Valencia, Valencia, Spain

2 CIBERFES, Institute of Health Research-INCLIVA, Valencia, Spain

3 Laboratory of Comparative Neurobiology, Instituto Cavanilles de Biodiversidad Y Biologia Evolutiva, University of Valencia, CIBERNED, Paterna, Valencia, Spain

4 Neuronal and Tissue Regeneration Laboratory, Centro de Investigación Príncipe Felipe, Valencia, Spain

5 Departament of Biotecnology, Universitat Politècnica de València, Valencia, Spain

6 Institute of Experimental Medicine, Czech Academy of Sciences, Prague, Czech Republic

7 Second Faculty of Medicine, Charles University, Prague, Czech Republic

8 Department of Psychobiology, Faculty of Psycology, University of Valencia, Valencia, Spain 


$\begin{array}{ll}\text { Cdk5 } & \text { Cyclin-dependent kinase 5 } \\ \text { CDKN2A } & \text { Cyclin-dependent kinase inhibitor 2A } \\ \text { CSF } & \text { Cerebrospinal fluid } \\ \text { DCX } & \text { Doublecortin } \\ \text { EdU } & \text { 5-Ethynyl-2'-deoxyuridine } \\ \text { GFAP } & \text { Glial fibrillary acid protein } \\ \text { ISO } & \text { Isoflurane } \\ \text { NeuN } & \text { Neuronal nuclear protein } \\ \text { NGS } & \text { Normal goat serum } \\ \text { NPCs } & \text { Neural progenitor cells } \\ \text { NSCs } & \text { Neural stem cells } \\ \text { PS1 } & \text { Presenilin 1 } \\ \text { PSA-NCAM } & \text { Polysialylated-neural cell adhesion } \\ & \text { molecule } \\ \text { RMS } & \text { Rostral migratory stream } \\ \text { SA } \beta \text { Gal } & \text { Senescence-associated } \beta \text {-galactosidase } \\ \text { SVZ } & \text { Subventricular zone }\end{array}$

\section{Background}

Two neurogenic regions are present in the postnatal anterior brain: the ventricular- subventricular area of the lateral ventricles (V-SVZ) and the subgranular layer of the dentate gyrus of the hippocampus [1]. In these regions, cell divisions continue to occur throughout life. Complex interactions between intrinsic molecular programmes and extrinsic determinants induce neural stem cells and neural progenitors to proliferate, differentiate and migrate [2-4].

The cellular organization of the V-SVZ is very well described both in mice and humans. In adult mice, four principal cell types have been described: the ependymal cells, the astrocyte-like type B cells, the type $\mathrm{C}$ cells and the type A cells. Ependymal cells (type E cells) line the ventricular cavity of the lumen of ventricles and display numerous cilia that are responsible for the flow of the cerebrospinal fluid (CSF). The astrocyte-like type B cells have been identified as stem cells with self-renewal property [5] and are characterized by the presence of intermediate filaments in their cytoplasm and by nestin-positive immunoreactivity [6]. Type $\mathrm{C}$ cells are large cells with invaginated nuclei and immature ultrastructural characteristics. They are considered as 'transit amplifying progenitors' giving rise rapidly to migratory or type A cells. These cells are responsible for the formation of the granular and periglomerular neurons in the olfactory bulb [7]. More recently, cellular migration has been also described to other regions such as the striatum, corpus callosum and nucleus accumbens [8-10].

However, the cell proliferative capacity is limited and can be modified both by physiological and pathological processes. When the cell loses this function, it enters in a senescent state in which its proliferative capacity is irreversibly abolished, but its vital activities are still taking place [11]. The first cause of senescence to be described was the shortening of telomeres. Other causes such as DNA mutations, loss of methylation of the CDKN2A gene associated with ageing, cytotoxic agents and oxidative stress can give rise to this cellular stage [11]. All these causes lead to an increase in the expression of proteins that stop the cell cycle and mainly provoke morphological changes, cell growth, flattening and lengthening, vacuolization, an increase in lysosomal content and upregulation of $\beta$-galactosidase enzyme (SA $\beta$ GAL) $[12,13]$.

In the last century, life expectancy has doubled, and therefore a significant increase in people reaching advanced ages has occurred. This advantage has also brought a change in the profile of the most prevalent diseases, being neurodegenerative and in particular Alzheimer's disease (AD), one of the main ones. Conventional pharmacological therapies fail to stop or recover brain functions, so in recent years research in tissue regeneration has become very relevant, and especially neuronal regeneration. However, although much progress has been made in the study of neural precursors, there is still a long way to go in this regard [14].

In $\mathrm{AD}$, the most common form of dementia, a decrease in proliferation and neurogenesis occurs. This deficit in neurogenesis may promote cognitive defects in AD [15]. This phenomenon has been described in neurospheres from mice models and AD patients [16, 17], and also in different transgenic mice of AD [18, 19]. Even some recent studies are describing a reduction in hippocampal neurogenesis in $\mathrm{AD}$ patients [20]. However, some authors doubt the existence of adult neurogenesis in the dentate gyrus [21].

Concerning V-SVZ neurogenesis, it has been poorly studied both in AD patients and in AD animal models. In this study, we want to clarify the proliferative and migration capacity of V-SVZ cells in a mice model of AD, the APP/PS1 transgenic mice. We have observed that type A clumps cells accumulate and type E cells decrease in APP/ PS1 compared to wild-type mice. Furthermore, migrating type A cells decrease in the rostral migratory stream (RMS) and are also arranged in a spatially different way respect wild-type mice closely to the ventricle surface. Biochemical changes that could explain this phenotype include: an increase in Cdh1 levels and a decrease in Cdk5, p35 and cyclin B1, indicating a cell cycle dysfunction. The number of V-SVZ cells in the S phase decreased in the AD model compared to WT mice. Finally, we show that accumulated cells are in a senescent state. We conclude that migration from V-SVZ to the olfactory bulb is impaired in APP/PS1 mice potentially contributing to a defective neuronal degeneration in $\mathrm{AD}$. 


\section{Materials and Methods}

\section{Animal Models}

B6C3-Tg (APPswe, PSEN1dE9)85Dbo (The Jackson Laboratory, USA) transgenic mice and wild-type (WT) mice from the same colony and littermates were used in this study at 3-6 months of age, both male and female. Mice were housed in groups (2-6 mice per cage) and maintained in a $12: 12$-h light-dark cycle at $23 \pm 1{ }^{\circ} \mathrm{C}$ and $60 \%$ relative humidity with access to food and water ad libitum. All procedures were performed in accordance to the protocols approved by 'Comisión de Ética en la Investigación Experimental, Vicerectorado de Investigación' of the University of Valencia (ref: A1510738650191, A1550947177828).

We also performed an experimental AD mice model by intraventricular infusion of beta-amyloid $(A \beta)$ peptide or PBS as control. Six-month-old WT mice were anaesthetized at $4 \%$ isoflurane (ISO) (C3H2ClF5O) (IsoFlo; Zoetis, Spain S.L.) and maintained at 1.5 to $2 \%$ ISO with an oxygen flow of $0.5 \mathrm{~L} / \mathrm{min}$. Anaesthesia was kept using a ' $\mathrm{T}$ de Eyre' system, and the position was fixed with a stereotaxic support (SR-6R; Nasishige, Japan). Atropine sulphate (0.05 mg/kg) (A0257; Sigma-Aldrich, USA) and buprenorphine $(0.1 \mathrm{mg} / \mathrm{kg}$ ) (Dechra Veterinary Products SLU) were also administrated intraperitoneally to avoid any pain or bradycardia symptoms. Between 0.05 and $0.1 \mathrm{~mL}$ of $5 \%$ lidocaine (Braun, Germany) was injected into the incision site, and the skull was surgically exposed. Small burr holes were drilled in the skull $0.1 \mathrm{~mm}$ anterior to bregma and $0.4 \mathrm{~mm}$ lateral to the mid-sagittal line. A Hamilton syringe $(65,458-01$; Hamilton, USA) was inserted into the burr holes reaching $2.2 \mathrm{~mm}$ below the surface of the skull where $1 \mu \mathrm{L}$ of $10 \mu \mathrm{M}$ oligomeric $\mathrm{A} \beta$ [22] was injected at a rate of $0.1 \mu \mathrm{L} / \mathrm{min}$ to avoid hydrocephalus $(n=4)$. For control mice, the same procedure with $1 \mu \mathrm{L}$ of PBS was performed $(n=4)$. After the procedure, the wounds were stitched, the area disinfected with povidone iodine (Desinpov; AGB, Spain) and oxytetracycline/polimixin (Terramicin; FarmaSierra, Spain), and the awaking was monitored. In all the subjects, the conditions after the surgery were normal. After $24 \mathrm{~h}$, the mice were sacrificed [23-26], the V-SVZ disaggregated and fresh cells used for analysis of $\beta$-galactosidase activity by flow cytometry.

\section{Primary Culture of Neural Precursor Cells}

Neural stem cells (NSCs) were obtained from V-SVZ and cultured to grow neurospheres. Briefly, 3-month-old WT $(n=6)$ and APP/PS1 $(n=6)$ mice were sacrificed by cervical dislocation, and the brains were quickly removed.
The V-SVZ were dissected, and the tissue obtained was mechanically dissociated to obtain a single cell suspension in $1 \mathrm{~mL} \mathrm{DMEM} / \mathrm{F} 12$ medium containing $0.6 \%$ glucose, $2 \mathrm{mmol} / \mathrm{L}$ L-glutamine, $9.6 \mathrm{~g} / \mathrm{mL}$ putrescine, $6.3 \mathrm{ng} / \mathrm{mL}$ progesterone, $5.2 \mathrm{ng} / \mathrm{mL}$ sodium selenite, $0.025 \mathrm{mg} / \mathrm{mL}$ insulin, $0.1 \mathrm{mg} / \mathrm{mL}$ transferrin and $2 \mathrm{~g} / \mathrm{mL}$ heparin. Cells were seeded at a final density of $25 \times 103$ cells in uncoated culture dishes (Corning, NY) in the presence of $20 \mathrm{ng} /$ $\mathrm{mL}$ epidermal growth factor and $20 \mathrm{ng} / \mathrm{mL}$ of fibroblast growth factor. After 3 to 4 days of culture, colonies of clonally derived neurospheres started to appear. All the experiments were performed at the third passage. A $\beta$ peptide $(10 \mu \mathrm{M})$ or vehicle was added to the culture medium and incubated for $24 \mathrm{~h}$.

To measure proliferation rate, we used 5-ethynyl-2'deoxyuridine (EdU, Thermo Fisher) labelling, which detects directly de novo DNA synthesis during phase S. Briefly, neurospheres were plated into chamber slides and allowed to settle for $30 \mathrm{~min}$. Then, half of the culture medium was replaced with fresh culture medium containing EdU at a final concentration of $10 \mu \mathrm{M}$, and cells were incubated for $3 \mathrm{~h}$. Following incubation cells were fixed with formaldehyde, and EdU was detected following manufacturer's instructions.

\section{Western Blot Analysis}

Dissected V-SVZ from 6-month-old APP/PS1 and WT mice were freeze-clamped in liquid nitrogen and stored at $-80{ }^{\circ} \mathrm{C}$ until processed. V-SVZ were homogenized in lysis buffer (Tris: $76.5 \mathrm{mM}$; pH: 6.8; SDS: 2\%; glycerol: $10 \%$, supplemented with sodium orthovanadate $(2 \mathrm{mM})$ and protease inhibitor (Sigma-Aldrich) in a proportion of $1 \mathrm{~mL}$ lysis buffer/100 mg brain tissue) and by using mechanical shear with a Potter-Glass-Teflon homogenizer (Rw20 DZM Homogenizer, Janke \& Kunkel), at $2000 \mathrm{rpm}$ in ice.

We measured the protein concentration present in the tissue homogenates by the Lowry protein assay (SigmaAldrich). Twenty micrograms of proteins from each sample was loaded in an SDS-polyacrylamide gel. Proteins were separated by electrophoresis and electro-transfected into a nitrocellulose membrane. The nitrocellulose membranes were blocked with $5 \%$ low-fat milk or $5 \%$ BSA (w/v) in $1 \times$ TBS-Tween for $1 \mathrm{~h}$ at room temperature (RT). The next primary antibodies were incubated overnight at $4{ }^{\circ} \mathrm{C}$ diluted in the appropriated blocking solution: cdh1 (DCS266 NBP1-54,465, 1:1000, Novus Biologicals), cdk5 (2506, Cell Signalling Technology, 1:1000), cyclin B1 (4138S, Cell Signalling Technology, 1:1000), $\gamma \mathrm{H} 2 \mathrm{X}$ (9718, Cell Signalling Technology, 1:1000), p16 (MA1-16,664, ThermoFisher, 1:500), $\alpha$-tubulin (sc-8035, Santa Cruz Biotechnology, 1:8000) and GAPDH (G9545, Sigma, 1:20,000). Finally, membranes were incubated for $1 \mathrm{~h}$ at RT with the corresponding secondary antibody: anti-mouse IgG H\&L 

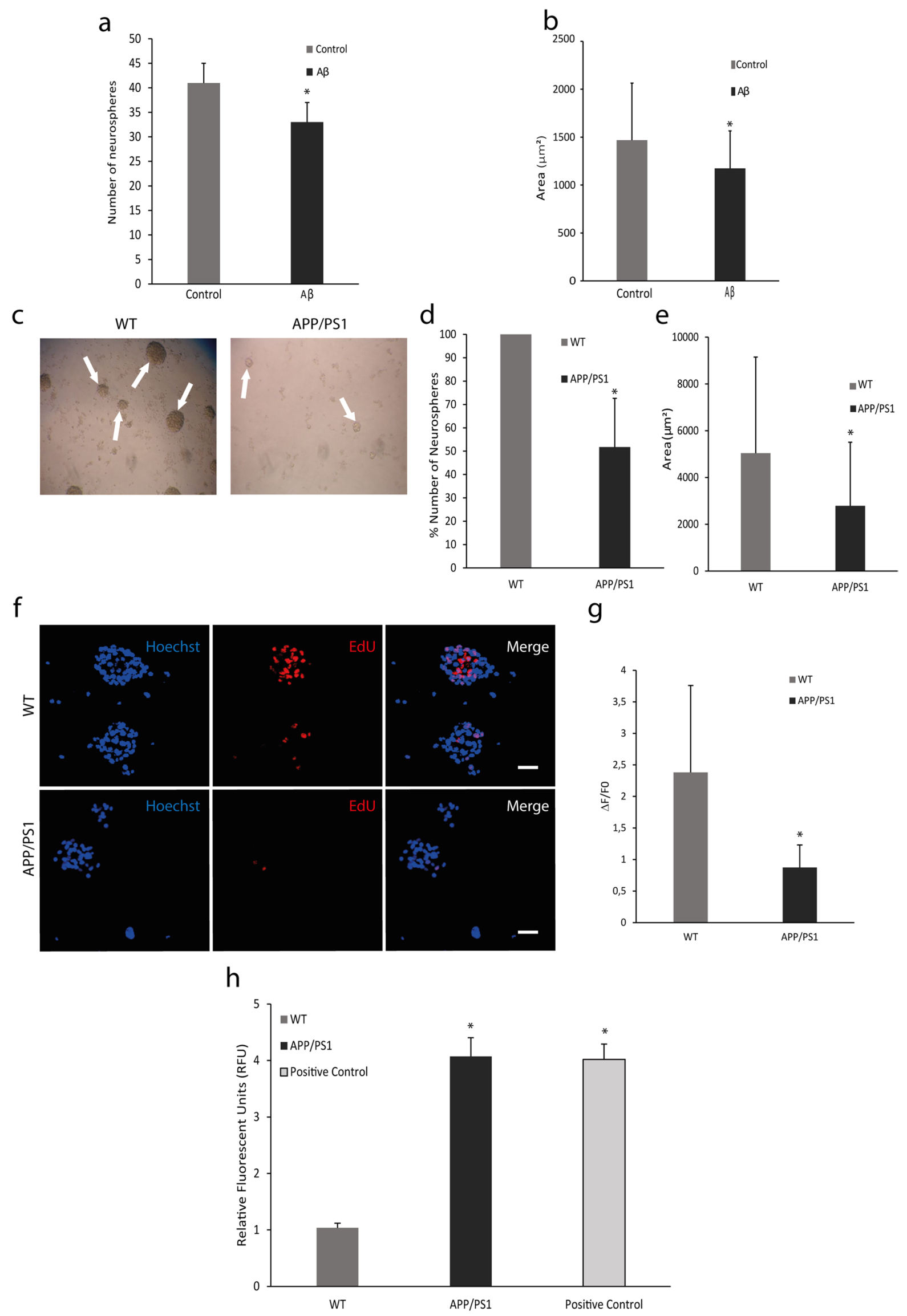
४Fig. 1 Proliferation rate and oxidative stress analysis. (a) Number of neurospheres from V-SVZ are less in the group incubated with $10 \mu \mathrm{M}$ $\mathrm{A} \beta$ respect to the control group. Mean values \pm SD. Student's $t$ test. ${ }^{*} p=0.0001$ vs. control $(t=5.527, d f=12) . n=6$. (b) Area $\left(\mu \mathrm{m}^{2}\right)$ of neurospheres from WT mice shows a decrease after incubation with $10 \mu \mathrm{M}$ A $\beta$. Mean values \pm SD. Student's $t$ test. $* p=0.0163$ vs. control $(t=2.459, d f=72) . n=6$. (c) Representative images of neurospheres from WT and APP/PS1 mice. (d) Number of neurospheres from V-SVZ WT is higher than those from APP/PS1 mice. Mean values \pm SD. Student's $t$ test. $* p=0.0003$ vs. WT. $(t=5.974, d f=8)$. $n=6$. (e) Area $\left(\mu \mathrm{m}^{2}\right)$ measured in neurospheres decrease in APP/PS1 mice respect to WT. Mean values $\pm \mathrm{SD}$. Student's $t$ test. ${ }^{*} p=1 \times 10^{-11}$ vs. WT ( $t=6.895, d f=448)$. $n=6$. (f) Representative images of neurospheres from WT and APP/PS1 mice labelled with EdU in red, which is incorporated to DNA during mitosis, and with Hoechst in blue marking nuclei. Scale bar $=50 \mu \mathrm{m}$. (g) Quantification of red fluorescence shows a decreased proliferation rate in neurospheres from APP/PS1 respect to WT. Mean values \pm SD. Student's $t$ test. * $p=0.0098$ vs. WT $(t=3.067, d f=12)$. $n=6$. (h) Mitochondrial hydrogen peroxide $\left(\mathrm{H}_{2} \mathrm{O}_{2}\right)$ production in SVZ cells is increased in APP/ PS1 mice compared with WT. Mean values \pm SD.ANOVA test. * $p=1 \times 10^{-6}$ vs. WT $\left(F_{2,10}=361 \cdot 3\right) . n=3$

Chain Specific Peroxidase Conjugate (401,215, Calbiochem, 1:6000), anti-rabbit IgG HRP-linked (7074S, Cell Signalling, 1:3000) or mouse monoclonal [KT98] Anti-Rat IgG2b H\&L (HRP) (ab106750, Abcam, 1:1000). Signal detection was performed using 'Luminata Classico Western HRP Substrate' (WBLUC0500, Millipore Corporation, Billerica, USA). Western blot images were obtained with a biomolecular imager (ImageQuant ${ }^{\mathrm{TM}}$ LAS 4000, GE Healthcare Bio-Sciences) and densitometry accomplished using Image Gauge 4.0 software.

\section{Flow Cytometry Assays}

V-SVZ tissue from 6-month-old APP/PS1 and WT mice was disaggregated and incubated at $37{ }^{\circ} \mathrm{C}$ for $35 \mathrm{~min}$ with EBSS medium enriched with papain, L-cysteine and EDTA. After centrifugation for $5 \mathrm{~min}$ at $600 \mathrm{~g}$, the pellet was resuspended in DMEM/F12. Cell cycle characterization was performed using PI/RNASE Solution (Immunostep) and following the manufacturer's recommended protocol. We also determined the content of mitochondrial hydrogen peroxide by MitoPY1 (SML0734, Sigma-Aldrich) which is an aryl-boronate derivate that in the presence of $\mathrm{H}_{2} \mathrm{O}_{2}$ releases a highly fluorescent product [27]. Finally, in infused A $\beta$ model, $\beta$-galactosidase activity was measured using FluoReporter lacZ Flow Cytometry Kit (F-1930, Molecular Probes).

\section{Immunohistochemistry Assays}

For immunohistochemistry assays, 6-month-old APP/ PS1 and WT mice were anaesthetized with a lethal dose of sodium pentobarbital (100 mg/kg 20\%; Dolethal Vetoquinol Madrid, Spain) and transcardially perfused with heparinized saline $(0.1 \%, \mathrm{pH} 7)$ and $4 \%$ paraformaldehyde solution in PBS (0.1 M, pH 7.4). Brains were post-fixed $24 \mathrm{~h}$ in $4 \%$ paraformaldehyde in PBS at $4{ }^{\circ} \mathrm{C}$ followed by 2 days in PBS with $30 \%$ sucrose at $4{ }^{\circ} \mathrm{C}$ for cryoprotection. Serial coronal or sagittal Sects. $(40 \mu \mathrm{m})$ were obtained by freezing microtome (Leica) and stored in PBS with $30 \%$ sucrose at $-20{ }^{\circ} \mathrm{C}$ until used.

Brain sections were washed in PBS containing $0.5 \%$ Triton X-100 solution (PBS-Tx), $3 \times$ at RT. Sections were blocked for $1 \mathrm{~h}$ at RT with PBS-Tx containing $10 \%$ of goat serum (NGS). After that, the tissue was incubated with the different primary antibodies overnight at $4{ }^{\circ} \mathrm{C}$ in PBS-Tx with $10 \%$ NGS. The following primary antibodies were used: p35/25 (C64B10) Rabbit mAb (2680, Cell Signalling Technology, 1:200), beta Galactosidase Monoclonal Antibody (S.394.9, Thermo Fisher, 1:3200), DIABLO Monoclonal Antibody (SMAC 17 1-87, ThermoFisher, 1:200), AntiDoublecortin antibody (ab18723, Abcam, 1:1000), GFAP Polyclonal Antibody (OPA1-06,100, ThermoFisher, 1:200), mouse anti-polysialic acid-NCAM (PSA-NCAM) monoclonal antibody (MAB5324, Chemicon, 1:400) and p-ATM (sc-47739, Santa Cruz Biotechnology, 1:500). Afterward, sections were rinsed $3 \times$ in PBS-Tx and incubated for $1.5 \mathrm{~h}$ at RT in a solution of $10 \%$ NGS in PBS-Tx with the secondary antibody: Anti-rabbit IgG $(\mathrm{H}+\mathrm{L}), \mathrm{F}\left(\mathrm{ab}^{\prime}\right) 2$ Fragment Alexa Fluor® 488 Conjugate (4412, Cell Signalling Tech, 1:1000); Anti-mouse IgG $(\mathrm{H}+\mathrm{L}), \mathrm{F}\left(\mathrm{ab}^{\prime}\right) 2$ Fragment Alexa Fluor® 647 Conjugate (4410, Cell Signalling Tech, 1:1000); Goat anti-Mouse IgG $(\mathrm{H}+\mathrm{L})$, Superclonal ${ }^{\mathrm{TM}}$ Recombinant Secondary Antibody Alexa Fluor 488 (A28175, Invitrogen, 1:1000); Goat pAb to Rb IgG Alexa Fluor 647 (ab150079, Abcam, 1:1000). Finally, sections were washed in PBS-Tx and incubated with DAPI (H1200, Vector, Burlingame, USA) for nuclear staining, mounted onto $0.5 \%$ pigskin gelatine-coated slides, and covered with $24 \times 60 \mathrm{~mm}$ cover slips (Knittel GLASS) adding a drop of fluorescence mounting medium (S3023, DAKO, Barcelona, Spain).

\section{Image Acquisition and Data Analysis}

Immunohistochemistry preparations were visualized with a confocal laser-scanning microscope (Leica TCS SP2 scanning multiphoton and confocal unit with an inverted DM1RB microscope; Ar-He-Ne). For quantification, 6 images were taken from at least 3 slices per staining and per condition, which was then averaged for each animal. Images containing the area of interest were analysed with ImageJ software. To compare protein levels, we used area proportions of the specific antibody signal normalized to background fluorescence. Pearson's coefficient in the images from the co-localization analysis was performed by the script developed by Moser et al. [28], and the percentage of co-localization was obtained by the plugin from ImageJ: co-localization threshold. 


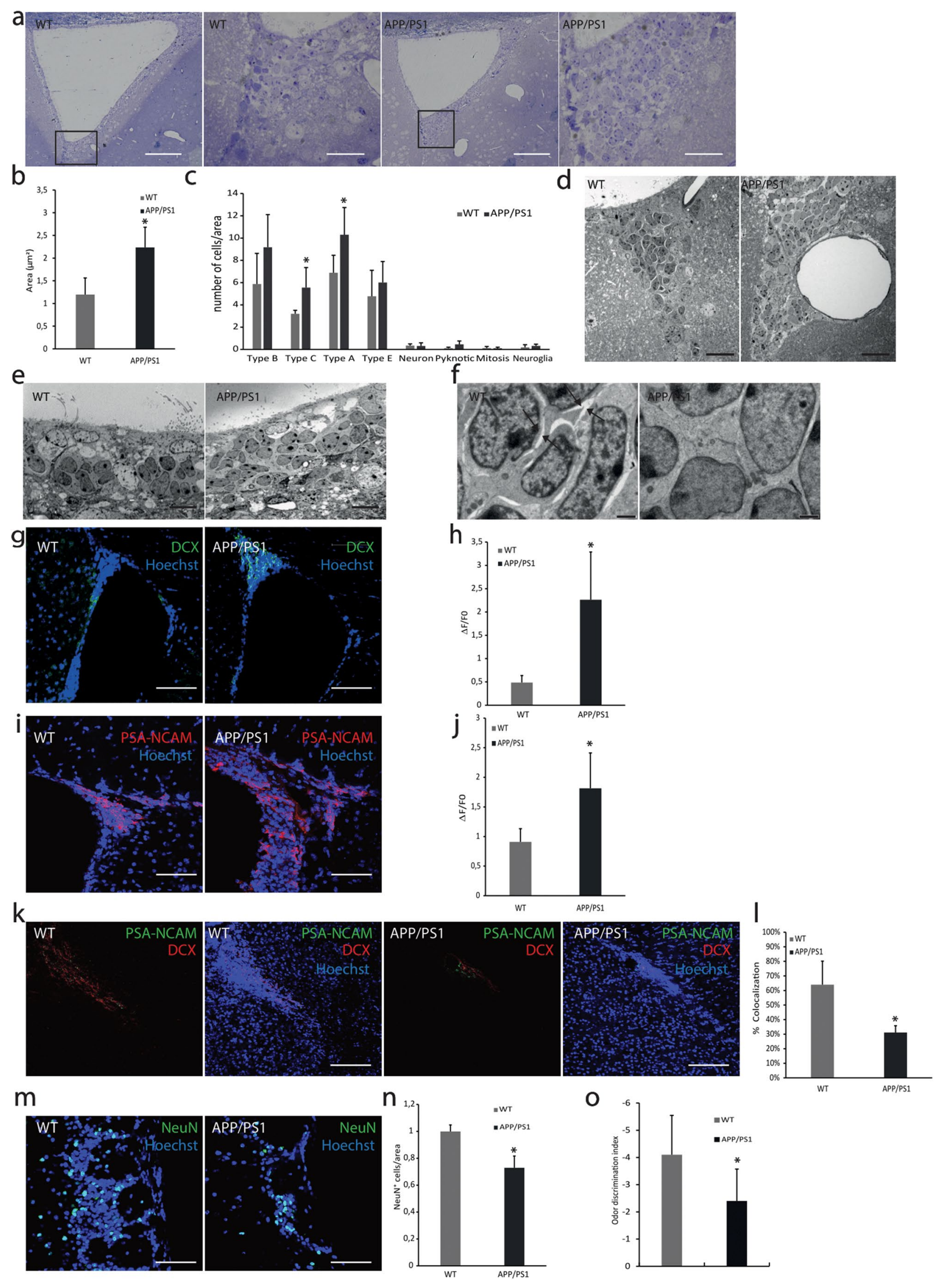


4Fig. 2 Morphological study of neural migration-related areas in APP/PS1 mice. (a) Images of toluidine blue-stained of V-SVZ slices show an accumulation of cells in APP/PS1 mice. Scale bar $=100 \mu \mathrm{m}$ (1 and 3) $25 \mu \mathrm{m}$ (2 and 4). $n=5$. (b) Area $\left(\mu \mathrm{m}^{2}\right)$ of the V-SVZ is increased in APP/PS1 mice due to the accumulation of cells. Scale bar $=100 \mu \mathrm{m}$. Mean values \pm SD. Student's $t$ test. $* p=0.0031$ vs. WT $(t=4.428, d f=7) . n=5$. (c) Quantification of each cell type expressed respect to total cells and analysed area in V-SVZ by electron microscopy. Mean values \pm SD. Student's $t$ test. $* p=0.0129(t=3.022$, $d f=10)$ (Type A vs. WT), ${ }^{*} p=0.0106(t=3.136, d f=10)$ (Type C vs. WT). $n=4$. (d) Electron microscopy analysis of the V-SVZ reveals larger blood vessels in APP/PS1 than in WT mice. Scale bar $=20 \mu \mathrm{m}$. $n=5$. (e) Electron microscopy analysis of the V-SVZ shows that type A cells are more disorganized in APP/PS1 compared to WT. Scale bar $=10 \mu \mathrm{m} . n=5$. (f) Electron microscopy analysis of the V-SVZ displays spaces in the extracellular matrix in WT which are absent in APP/PS1. Scale bar $=1 \mu \mathrm{m} . n=5$. (g) Confocal microscopy analysis of V-SVZ slices from WT and APP/PS1 mice labelled with anti-DCX (green) and with Hoechst (nuclei, blue). Representative images of three independent experiments. Scale bar $=75 \mu \mathrm{m}$. (h) Quantification of green fluorescence fold change shows an increase of $\mathrm{DCX}^{+}$cells in APP/PS1 mice. Mean values \pm SD. Student's $t$ test. ${ }^{*} p=0.0057$ vs WT ( $t=4.194, d f=6$ ). $n=3$. (i). Representative images of PSANCAM (red) in V-SVZ from WT and APP/PS1 mice. Hoechst (blue) was used to identify cell nuclei. Scale bar $=75 \mu \mathrm{m}$. (j) Quantification of red fluorescence fold change shows an increase in PSA-NCAM expression in APP/PS1 mice. Data are shown as mean \pm SD. Student's $t$ test. * $p=0.01$ vs. WT $(t=3.500, d f=7) . n=4$. (k) Representative images of the RMS from WT and APP/PS1 mice labelled with DCX (red) and PSA-NCAM (green). Hoechst (blue) was used to identify cell nuclei. Scale bar $=150 \mu \mathrm{m}$. (I) Quantification of co-localization of red (PSA-NCAM) and green (DCX) fluorescence shows a decrease of migratory cells in the RMS from APP/PS1 mice. Data are shown as mean \pm SD. Student's $t$ test. $* p=0.0026$ vs WT $(t=4.924$, $d f=6$ ). $n=3$. (m) Representative images of OB from WT and APP/ PS1 mice labelled with NeuN (red). Hoechst (blue) was used to identify cell nuclei. Scale bar $=75 \mu \mathrm{m}$. (n) Quantification $\mathrm{NeuN}^{+}$ cells shows a decrease of mature neurons in the OB from APP/PS1 mice. Data are shown as mean \pm SD. Student's $t$ test. $* p=0.0006$ vs WT $(t=6.555, d f=6) . n=3$. (o) Analysis of olfactory capacity shows a decrease in the APP/PS1 mice. Data are shown as mean \pm SD. ANOVA test. ${ }^{*} p=0.012$ vs WT $\left(F_{1,18}=7.811\right) . n=10$

\section{Odour Habituation Test}

Olfactory deficits were screened following the procedure of Wesson et al. [29] using the odor-habituation 201 test [30] in 6-month-old APP/PS1 and WT mice. Odours ( $n=7$; heptanone, isoamyl acetate, limonen, ethyl valerate, pentanol, propyl butyrate and nonane; Sigma-Aldrich, St. Louis, MO) were diluted $1 \times 10^{-3}$ in mineral oil and applied to a cottonapplicator stick. To prevent contact of the liquid odor with the animal, the stick was enclosed in an odourless plastic tube. This control method of odor presentation permits the minimization of visual and somato-sensory influences. Animals were tested in their own home cage to minimize potential influences of stress or anxiety on the behavioural measures. Testing took place during the dark phase of the animals' day. Odours were delivered for 4 successive trials ( 1 block), $20 \mathrm{~s}$ each, separated by 30-s inter-trial intervals, by inserting the odor stick into a port on the top of the animal's home cage. The number of approaches, defined as snout-oriented sniffing within $1 \mathrm{~cm}$ of the odor presentation port, was registered. Odor presentation and mice were tested in a counter-balanced order. For analysis of olfactory behaviour data, odor investigation durations within individual trials were collapsed across all odours. To calculate habituation index, the normalized investigatory values from all $4^{\text {th }}$ trial odor presentations were subtracted from the corresponding $1^{\text {st }}$ trial odor presentations.

\section{Electron Microscopy Analysis}

For electron microscopy studies, 6-month-old mice were perfused with $2 \%$ paraformaldehyde- $2.5 \%$ glutaraldehyde. We used 4 WT and 6 APP/PS1 mice, and 2 different brain levels of each mouse were studied. Brains were dissected out and post-fixed in the same fix solution. Coronal $200-\mu \mathrm{m} \mathrm{sec}-$ tions were obtained using a vibratome (Leica VT-1000, Heidelberg, Germany) and post-fixed with $2 \%$ osmium, rinsed, dehydrated and embedded in Durcupan resin (Sigma, St Louis, MO, USA). Semithin Sects. $(1.5 \mu \mathrm{m})$ were obtained, using an ultramicrotome (Leica EM UC-6, Heidelberg, Germany) with a diamond knife, and stained lightly with $1 \%$ toluidine blue to select the regions of interest. Ultra-thin Sects. $(0.08 \mu \mathrm{m})$ were obtained using an ultramicrotome (Leica EM UC-6) with a diamond knife and stained with lead citrate (Reynolds solution). Images were analysed with a transmission electron microscope (FEI Tecnai G2 Spirit BioTwin, Hillsboro, OR, USA) using a digital camera (Morada, Soft Imaging System, Olympus, Tokyo, Japan).

\section{Statistical Analysis}

Results are expressed as mean values $\pm \mathrm{SD}$, of at least three independent experiments. Generally, experiments were performed as duplicates, within each independent experiment. We used the Student's $t$ test to compare two means in parametric samples and the Mann-Whitney test for non-parametric samples. When we compared more than two means, we used the analysis of variance (ANOVA) test for parametric samples and the Kruskal-Wallis test for non-parametric samples. The null hypothesis was accepted at the level of $p \leq 0.05$.

\section{Results}

\section{Proliferation Rate Decreases in Neurospheres from APP/PS1 Mice}

First, we wanted to find out if the $A \beta$ peptide influences the proliferative capacity of neuronal stem cells in culture. For this purpose, we incubated neurospheres from V-SVZ of WT 
a
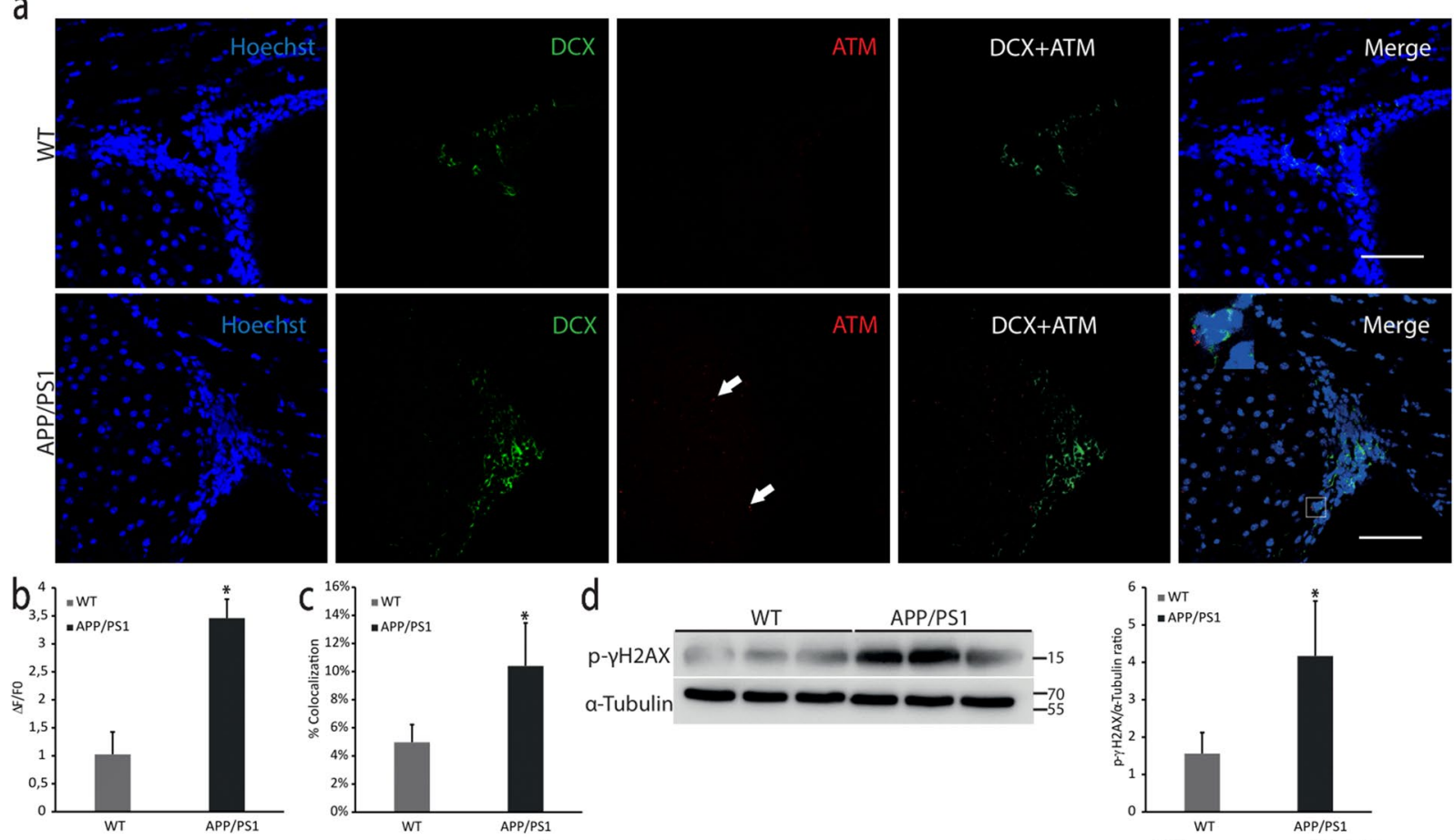

e

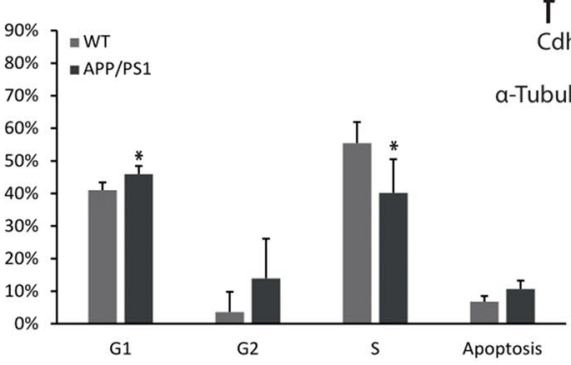

h

G1
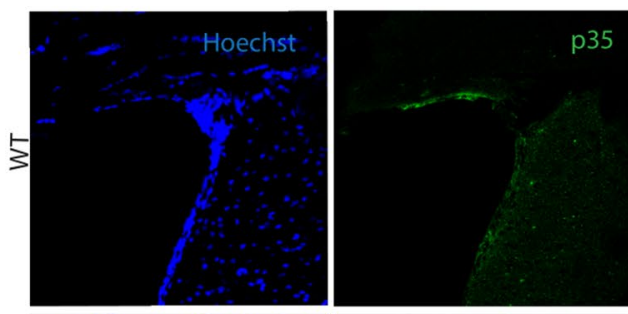

35

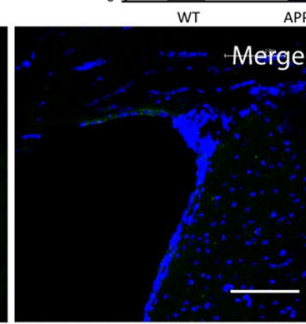

APP/PS1

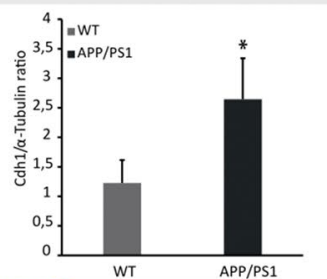

Merge

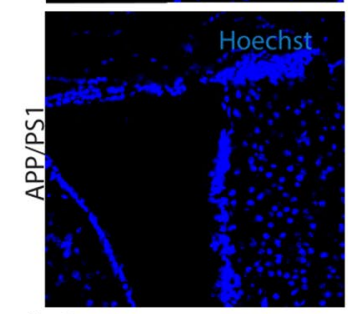

Merge
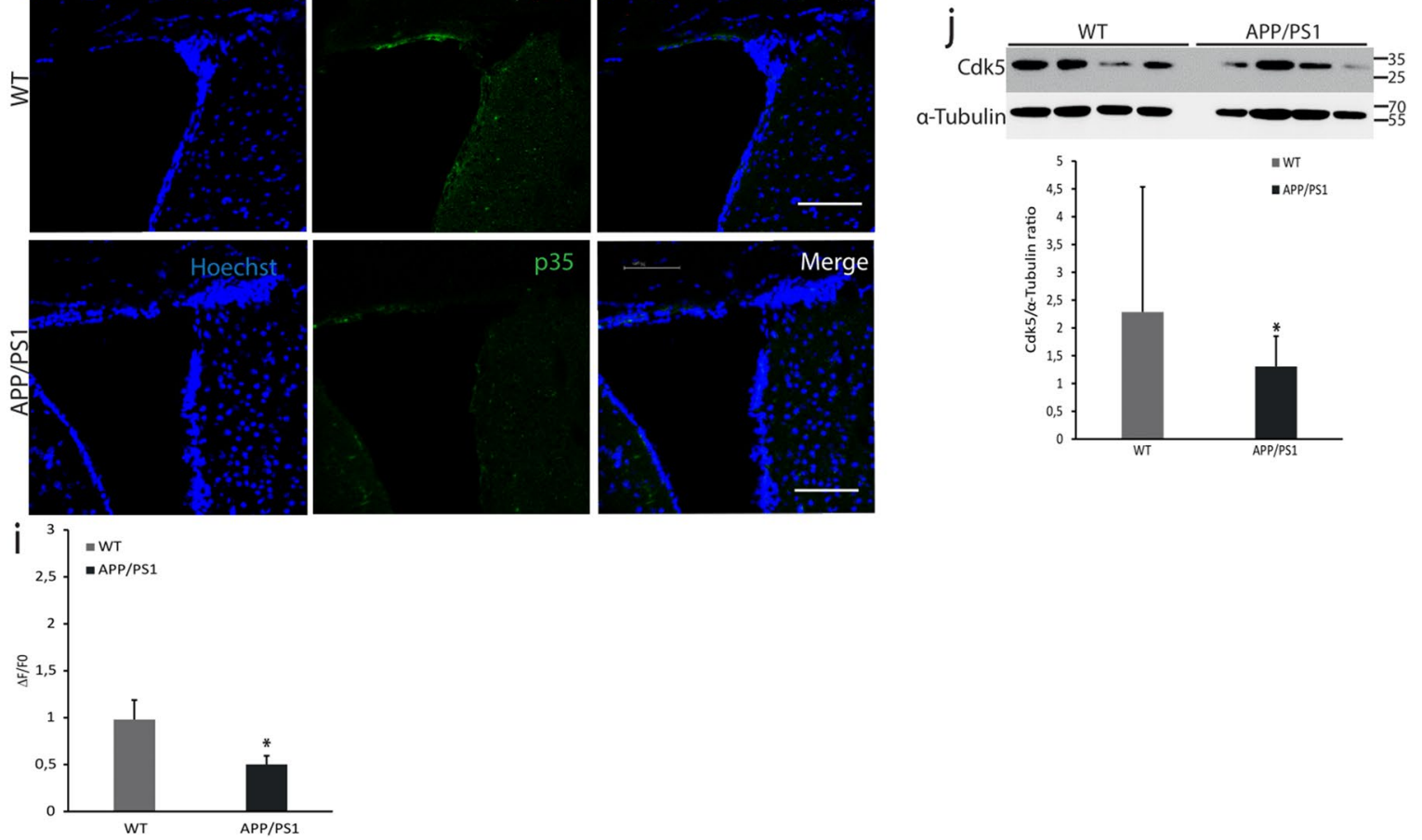
4Fig. 3 DNA damage and cell cycle study. (a) Confocal microscopy analysis of V-SVZ slices from WT and APP/PS1 mice. AntiATM in red, anti-DCX in green and nuclei stained with Hoechst in blue. Scale bar $=75 \mu \mathrm{m}$. (b) Quantification of red fluorescence fold change shows an increase of ATM content in APP/PS1 mice. Mean values \pm SD. Student's $t$ test. $* p=0.0001$ vs WT $(t=11.35, d f=6)$. $n=3$. (c) Quantification of co-localization of $\mathrm{ATM}^{+}$cells (red) and $\mathrm{DCX}^{+}$cells (green) indicates that $\mathrm{DCX}^{+}$cells express more ATM in APP/PS1 mice. Mean values \pm SD. Student's $t$ test. $* p=0.007$ vs WT ( $t=4.017, d f=6) . n=3$. (d) Western blot analysis of p- $\gamma \mathrm{H} 2 \mathrm{AX}$ levels in V-SVZ homogenates from WT and APP/PS1 mice. Blots of three independent experiments were quantified by densitometry and normalized with $\alpha$-tubulin levels. Mean values \pm SD are shown. Student's $t$ test. $* p=0.0066$ vs. WT $(t=4.063, d f=6)$. (e) Flow cytometry characterization of the cell cycle of V-SVZ cells from WT and APP/PS1 mice shows that cells in the S phase are less in APP/PS1 than in WT mice. Mean values \pm SD. Student's $t$ test. ${ }^{*} p=0.0224$ vs WT $(t=3.054, d f=6) . n=3$. (f) Representative images of western blot of Cdh1 in V-SVZ from WT and APP/PS1 mice. Blots were quantified by densitometry and normalized with $\alpha$-tubulin levels; mean values $\pm \mathrm{SD}$ of four independent experiments are shown. Student's $t$ test. ${ }^{*} p=0.0018$ vs. WT $(t=4.595, d f=8)$. (g) Western blot of cyclin B1 in V-SVZ from WT and APP/PS1 mice. Blots were quantified by densitometry and normalized with $\alpha$-tubulin levels. Mean values \pm SD of three independent experiments are shown. Student's $t$ test. $* p=0.0021$ vs. WT $(t=5.151, d f=6)$. (h) Representative images of p35 levels (green) in V-SVZ from WT and APP/PS1 mice. Hoechst (blue) was used to identify cell nuclei. Scale bar $=75 \mu \mathrm{m}$. (i) Quantification of green fluorescence fold change shows a decrease in the $\mathrm{p} 35$ expression in APP/PS1 mice. Mean values \pm SD. Student's $t$ test. $* p=0.0021$ vs WT $(t=5.133, d f=6) . n=3$. (j) Western blot of Cdk5 levels shows a decrease in V-SVZ from APP/PS1 compared to WT mice. Data are shown as mean values \pm SD. Student's $t$ test. ${ }^{*} p=0.0266$ vs WT $(t=2.279, d f=54) . n=4$

mice with $10 \mu \mathrm{M}$ oligomeric $\mathrm{A} \beta$ for $24 \mathrm{~h}$. Figure 1a shows that the number of neurospheres decreased after $A \beta$ treatment. Moreover, the area of the neurospheres was lower in the A $\beta$-treated group compared to the PBS group (control) (Fig. 1b). These results were also verified in neurospheres from APP/PS1 mice (Fig. 1c-e). The incorporation of EdU to the DNA (Fig. 1f) showed a decrease in the proliferative capacity of neurospheres in APP/PS1 vs. WT (Fig. 1g). Then, we wanted to know if this decrease is due to the presence of reactive oxygen species (ROS)/oxidative stress. To determine in vivo oxidative stress in the V-SVZ cells from transgenic AD mice, we used a flow cytometer assay labelling with MitoPY1, a fluorescent dye that specifically determines $\mathrm{H}_{2} \mathrm{O}_{2}$ levels. We observed an increase of $\mathrm{H}_{2} \mathrm{O}_{2}$ levels in the transgenic model compared to controls (Fig. 1h).

\section{Migrating Precursor Cells Accumulate in V-SVZ from APP/PS1 Mice}

We wondered whether the reduced proliferation rate and oxidative stress induced by $\mathrm{A} \beta$ could affect the cellular organization of V-SVZ. For this purpose, we studied the structure of the V-SVZ of both WT and APP/PS1 mice. In
APP/PS1 mice, we found cellular accumulation specifically in the dorsal part and in the fusion zone of the lateral ventricles (Fig. 2a). The total area of the V-SVZ was significantly increased in APP/PS1 mice compared to WT (Fig. 2b). To characterize these cellular clumps, we studied the ultrastructure of the regions (Fig. 2d-f). Based on the V-SVZ cellular classification reported by Doetsch et al., we obtained the percentage of each cellular type [6]. We observed a statistically significant increased number of type A cells, usually surrounded by big blood vessels, and an increase of type C cells in APP/PS 1 compared to WT mice (Fig. 2c, d). Besides, APP/PS1 type A cells appear more disorganized than WT cells (Fig. 2e), and without extracellular matrix spaces needed for cell migration (Fig. 2f).

Immunolabeling confirmed that accumulated cells in APP/PS1 mice were type A cells since they expressed immaturity marker doublecortin (DCX) and the migrating neural progenitor cell marker, PSA-NCAM (Fig. $2 \mathrm{~g}-\mathrm{j}$ ). Furthermore, to study the migration capacity of type A cells, we

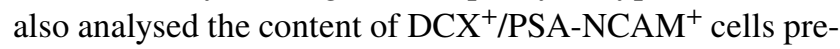
sent at the proximal RMS. We observed a reduction of $32.9 \%$ in type A cells in the RMS from APP/PS1 mice compared with WT (Fig. 2k, 1). Additionally, we measured the number of mature neurons $\left(\mathrm{NeuN}^{+}\right)$in the olfactory bulbs and observed a significant decrease in the AD transgenic mouse model (Fig. 2m, n). Importantly, APP/PS1 mice exhibited serious deficiency discriminating odours compared with WT animals at the same age (Fig. 2o).

\section{Cell Cycle Modifications in V-SVZ Cells from APP/PS1}

Taking together oxidative stress and cell accumulation in the V-SVZ of the transgenic model, we want to figure out possible molecular explanations. One of the main oxidative damage targets is DNA inducing possible alterations in the cell cycle. To determine DNA damage in V-SVZ tissue we measured the levels of p-ATM and its target, the phosphorylated histone $\gamma \mathrm{H} 2 \mathrm{AX}(\mathrm{p}-\gamma \mathrm{H} 2 \mathrm{AX})$. Figure $3 \mathrm{a}-\mathrm{d}$ shows an increase in p-ATM and p- $\gamma \mathrm{H} 2 \mathrm{AX}$ levels in APP/ PS1 V-SVZ compared to WT. It is interesting to note that the increase in p-ATM co-localizes with $\mathrm{DCX}^{+}$cells (Fig. 3a).

Increased levels of $\mathrm{p}-\gamma \mathrm{H} 2 \mathrm{AX}$ are an established marker of replicative stress; therefore, we characterized the cell cycle by flow cytometry and some cell cycle-related proteins. We found a statistically significant increase of cells in the G1 phase (Fig. 3e) and a reduction of cells in the $S$ phase in APP/PS 1 mice compared with controls. Levels of Cdh1, an important co-factor of the cell cycle master regulator $\mathrm{APC} / \mathrm{C}$, increased in V-SVZ from APP/PS1 (Fig. 3f). APC/C is an E3 ubiquitin-ligase that labels proteins for degradation. This result fits with a cell cycle arrest in the G1 

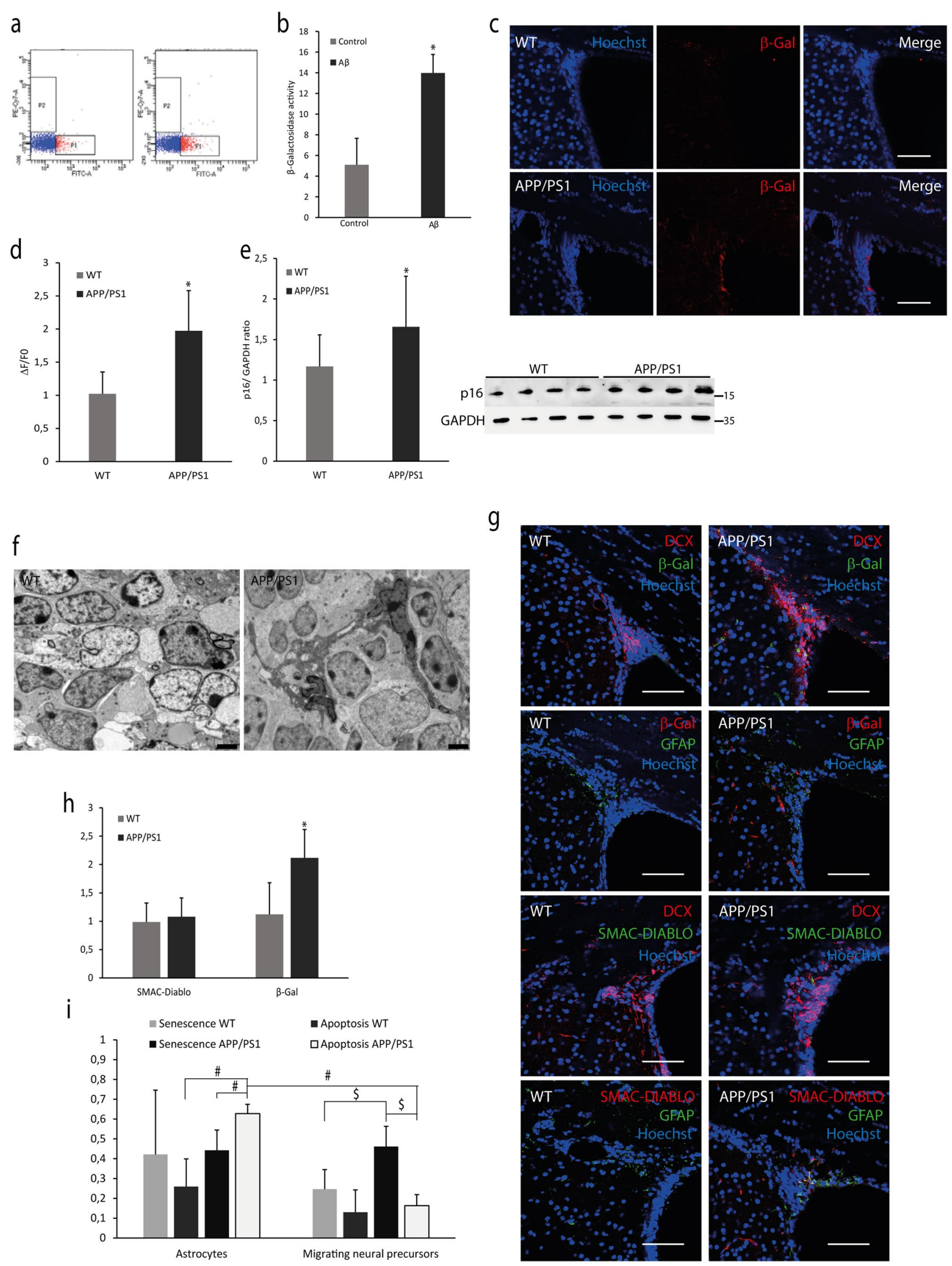
४Fig. 4 Senescence and apoptosis in the V-SVZ of APP/PS1. (a) Flow cytometry representative plots of $\beta$-Gal activity in V-SVZ cells measured after intraventricular infusion of $A \beta$. (b) Quantification of $\beta$-Gal activity reveals an increase in $\mathrm{A} \beta$-treated mice compared to controls. Mean values \pm SD. Student's $t$ test. ${ }^{*} p=0.0001$ vs. control $(t=7.340$, $d f=8) n=4$. (c) Confocal microscopy representative images of $\beta$-Gal levels (red) in V-SVZ from WT and APP/PS1 mice. Hoechst (blue) was used to identify cell nuclei. Scale bar $=75 \mu \mathrm{m}$. (d) Quantification of red fluorescence fold change shows that $\beta$-Gal expression increases in V-SVZ APP/PS1 compared with WT. Mean values \pm SD. Student's $t$ test. $* p=0.0044$ vs. WT $(t=3.777, d f=9) . n=5$. (e) Representative western blot image of p16 levels in V-SVZ from WT and APP/ PS1 mice. Densitometry of bands shows an increase in p16 expression in APP/PS1 compared with WT. Data are shown as mean \pm SD. Student's $t$ test. * $p=0.0231$ vs. WT $(t=2.433, d f=23) . n=4$. (f) Representative electron microscopy images of the V-SVZ from WT and APP/PS1. Magnification reveals the presence of apoptotic astrocytes in the V-SVZ from APP/PS1, and arrows indicate live astrocytes in WT mice. Scale bar $=2 \mu \mathrm{m}$. $n=5$. (g) Representative images of $\beta$-Gal, DCX, GFAP and SMAC-DIABLO levels in V-SVZ from WT and APP/PS1 mice. Hoechst (blue) was used to identify cell nuclei. Scale bar $=75 \mu \mathrm{m}$. (h) Quantification of fluorescence fold change shows different levels of senescence $(\beta-\mathrm{Gal})$ in the V-SVZ of APP/PS1 mice compared to WT. Mean values \pm SD. Student's $t$ test. $* p=0.0055$ vs. WT $(t=4.235, d f=6) . n=3$. (i) Co-localization of apoptosis/senescence markers with astrocytes/migrating neural precursors markers. Data are shown as mean \pm SD. ANOVA test. Statistics values are: $F_{7,24}=8.107 ; \$ p=0.0007$ (apoptosis vs. senescence in APP/PS1 migrating neural precursors); $p=0.009$ (migrating neural precursors senescence in APP/PS1 vs. WT). $\# p=0.0069$ (senescence vs. apoptosis in astrocytes from APP/PS1); $p=0.0001$ (apoptosis in APP/PS1 migrating neural precursors vs. apoptosis in APP/PS1 astrocytes); $p=0.0009$ (astrocytic apoptosis in APP/PS1 vs. WT). $n=3$

phase since APC/C-Cdh1 activity is crucial to passing through the $\mathrm{G} 1$ phase into the $\mathrm{S}$ phase. Consistent with this result, one of the APC/C-Cdh1 targets, cyclin B1 was significantly decreased in these animals (Fig. $3 \mathrm{~g}$ ). The Cdk5/p35 complex is a kinase that phosphorylates and therefore inactivates Cdh1. In this line, we observed a decrease in p35, the coactivator of Cdk5, (Fig. 3h-i), and in Cdk5 levels (Fig. 3j), indicating a reduction of Cdk5 activity.

\section{Study of Senescence and Apoptosis in V-SVZ}

To figure out whether the cell cycle arrest that we observe in the V-SVZ from APP/PS1 triggers a senescent state, we measured the amount of SA $\beta G A L$, one of the main markers of a senescent state. Microinjection of $10 \mu \mathrm{M}$ soluble $\mathrm{A} \beta$ peptide in the lateral ventricles produces a SA $\beta$ GAL phenotype in the V-SVZ of WT mice (Fig. 4a, b). We also measured this senescent state by immunofluorescence in V-SVZ tissue from WT and APP/PS1 mice, and we observed an increase in the last ones (Fig. 4c, d). Furthermore, we determined the content of p16, another senescence marker, in V-SVZ from WT and APP/PS1 mice, and we reported an increase in the transgenic model (Fig. 4e).
Finally, we observed by electron microscopy a relevant amount of apoptotic astrocytes in the V-SVZ from APP/PS1 (Fig. 4f). We decided to co-localize DCX (a neuronal immature marker) or GPAP (astrocyte marker) with a senescence marker ( $\beta$-gal) or an apoptosis marker (Smac/DIABLO) (Fig. $4 \mathrm{~g}-\mathrm{i}$ ). Our results showed that there are more senescent migrating neurons than apoptotic migrating neurons in the V-SVZ from APP/PS1 while astrocytes displayed more apoptosis than senescence. Furthermore, there is an increase of both $\mathrm{DCX}^{+} / \beta-\mathrm{gal}^{+}$and GFAP $+\mathrm{DIABLO}^{+}$cells in APP/ PS1 respect to WT (Fig. 4i). Therefore, we can assume that increase in the total senescence shown in the V-SVZ of APP/ PS1 (Fig. 4d, h) comes from the accumulated type A cells.

\section{Discussion}

Here, we show that $A \beta$ toxicity induces NPCs to enter irreversible proliferative arrest with features of cellular senescence. APP/PS1 mice, which generate large amounts of brain A $\beta$ peptide, have increased activation of ATM, an apical PI3K-like serine/threonine kinase that marks DNA lesions through phosphorylation of the histone $\mathrm{H} 2 \mathrm{~A}$ variant $\mathrm{H} 2 \mathrm{AX}(\gamma \mathrm{H} 2 \mathrm{AX})$ [31-34]. DNA damage could be probably caused by the broadly demonstrated capacity of $A \beta$ of increasing ROS production [35]. $\gamma \mathrm{H} 2 \mathrm{AX}$ is a marker of replicative senescence, cellular response to damaging stress characterized by a non-proliferative but viable state [36-38]. In our study we have observed that direct microinjection of $A \beta$ inside the lateral ventricles increases the $\beta$-gal activity in V-SVZ cells, an established marker of senescence. Moreover, we show that V-SVZ type A cells from APP/PS1 mice accumulated in huge cellular clumps. These cells display an increase in SA- $\beta$-gal phenotype and p16 expression, indicating a senescence state. Type A cells are migratory cells (neuroblasts) that should be moved to the olfactory bulb along the RMS $[1,39]$. APP/PS1 mice have a reduced number of type A cells in the RMS compared to WT. This result suggests a reduction in the olfactory bulb neurogenesis which fits with Scopa et al., which also reported an increase in neuroblast number in V-SVZ due to the presence of $\mathrm{A} \beta$ [40]. Moreover, we observe by electron microscopy that these senescent and accumulated cells are surrounded by a significant number of thick blood vessels. In this sense, angiogenesis has been linked with the senescent-associated secretome in many types of cells [41-43]. Furthermore, angiogenesis is related to the leading process of the migrating NPCs, suggesting that this interaction provides directional guidance to the NPCs [44].

In order to elucidate a plausible molecular explanation for the cell cycle arrest, we studied the master cell cycle regulator APC/C. APC/C is an E3 ubiquitin-ligase that needs as co-factor Cdh1. APC/C-Cdh1 participates in the 
Fig. 5 Graphical representation of the proposed molecular pathway.A $\beta$ peptide increases ROS levels in migrating neural precursors (type A cells) leading to DNA damage which provokes a cell cycle arrest associated with an increase of Cdh1 levels and a decrease of its targets cyclin B1 and Cdk5/p35. This cell cycle arrest triggers to a senescence state. Senescent cells accumulate in the V-SVZ and are unable to migrate. Created with BioRender.com

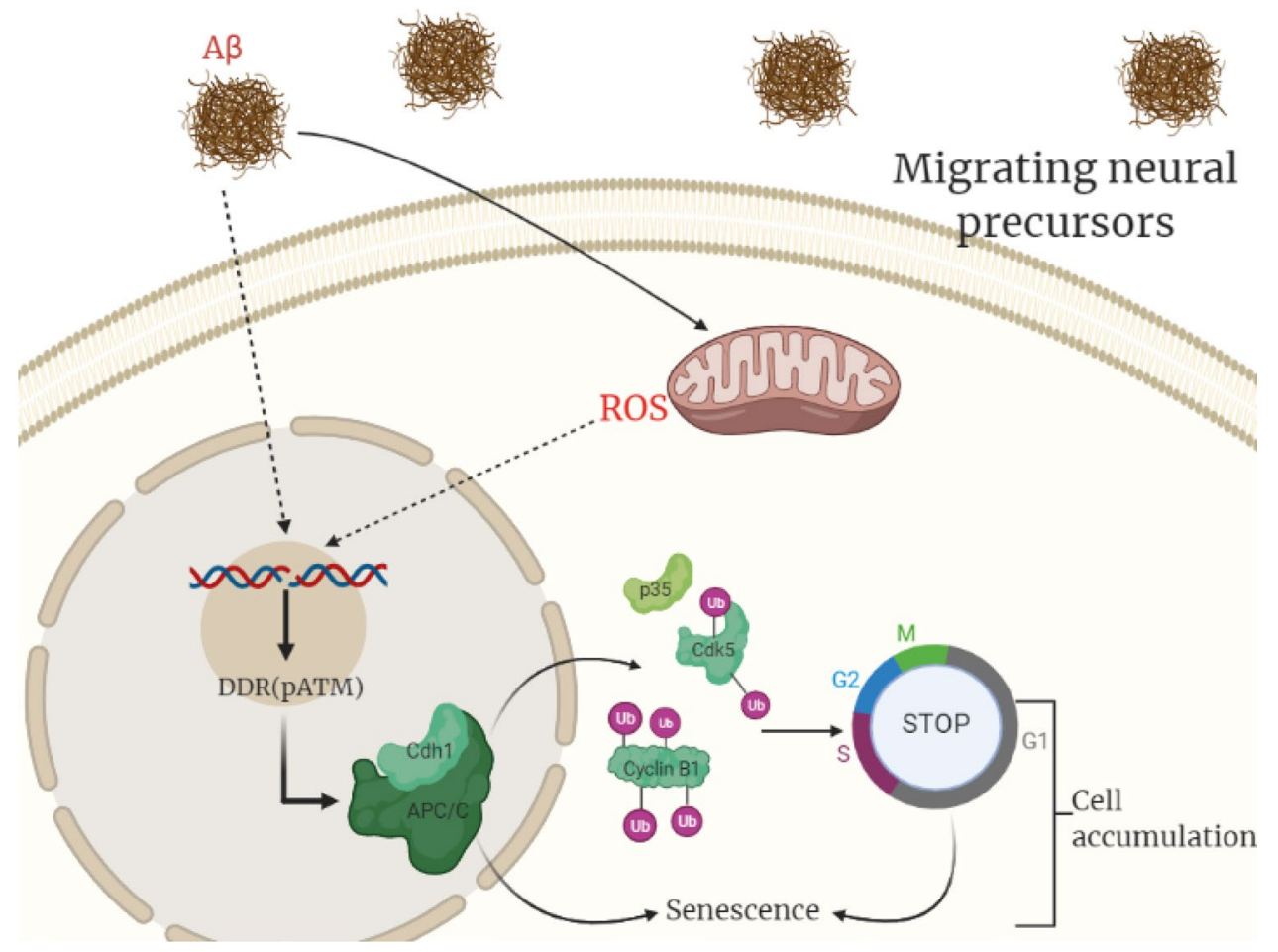

regulation of G1/S transition and also controls the DNA damage response (DDR) $[45,46]$. We observe that Cdh1 levels increase in V-SVZ from APP/PS1 mice indicating that APC/C could be more active [47]. In fact, DDR leads to a degradation of dimethyltransferases of the histone $\mathrm{H} 3 \mathrm{~K} 9$, mediated by APC/C-Cdh1 activation, and this has been associated with senescence secretory phenotype such as IL-6 secretion [48]. One of the main targets of APC/C$\mathrm{Cdh} 1$ is cyclin B which is polyubiquitinated and degraded to pass to phase S [49-52]. We show that the levels of cyclin B1 decrease in APP/PS1 animals compared to WT, which fits with the observed lower number of cells in phase S. We also show decreased levels of the complex $\mathrm{Cdk} 5 / \mathrm{p} 35$ in the transgenic mice, another known target of APC/C-Cdh1 [50] and which is also involved in the neural migration [53]. Figure 5 summarizes our molecular findings.

Interestingly, although we find apoptotic and senescent cells in the V-SVZ of the APP/PS1 mice model, we show that NPCs die mostly by senescence, and on the contrary, astrocytes die mainly by apoptosis. Schneider et al. obtained similar results. They showed that NPCs, following ionizing radiation-induced DNA damage, enter irreversible proliferative arrest with features of cellular senescence and, then, differentiate into astrocytes. This was promoted by ATM [54]. Further, they demonstrated that the differentiated astrocytes enter into apoptosis [55]. Astrocytes have an important role in neural migration so the apoptosis of these cells could also contribute to the migration failure of the migrating neural precursors from the V-SVZ due to its important role in this process [56].

Finally, our results are focused on a new perspective on the role of $\mathrm{V}-\mathrm{SVZ}$ in neurodegeneration, specifically in AD. The presence of senescence in this neurogenic niche which induces a failure in the migration to the olfactory bulb could fit with the presence of early anosmia seen in AD patients and previously described by many authors, and as we have observed in our mice model [57-59]. In fact, it has been reported that in the adult human brain the V-SVZ/OB via remains active but dimmed compared with other species [60]. Furthermore, the V-SVZ under damage supply astrocytes, oligodendrocytes and new neurons to different parts of the adult brain like the corpus callosum or the striatum, areas seriously affected in the AD pathology [10, 61-64]. The NPC senescence demonstrated to open a new therapeutic target with senolytic compounds such as metformin, rapamycin, aspirin and resveratrol, to improve neurogenesis in the V-SVZ [65-67].

Acknowledgements We thank Mrs Marilyn Noyes for her kind help in reviewing the manuscript.

Author Contribution A.L. and D.E. designed the study. D.E., E.G. and N.M. performed the molecular biology analysis. J.M.G-M. and M.M.M-N. performed the electron microscopy analysis. D.E., E.G., N.M. and M.M.M-N. analysed and interpreted data. A.L., J.V. and D.E. prepared the manuscript draft. A.L. and J.V. supervised the study and obtained funding. All authors read and approved the final manuscript. 
Funding Open Access funding provided thanks to the CRUE-CSIC agreement with Springer Nature. This work was supported by the following grants: Instituto de Salud Carlos III CB16/10/00435 (CIBERFES), (PID2019-110906RB-I00/AEI/10.13039/501100011033) from the Spanish Ministry of Innovation and Science, PROMETEO/2019/097 from 'Consellería, de Sanitat de la Generalitat Valenciana' and EU Funded H2020- DIABFRAIL-LATAM (Ref: 825546), European Joint Programming Initiative 'A Healthy Diet for a Healthy Life' (JPI HDHL) and of the ERA-NET Cofound ERA-HDHL (GA N ${ }^{\circ}$ 696295 of the EU Horizon 2020 Research and Innovation Programme). Part of the equipment employed in this work has been funded by Generalitat Valenciana and co-financed with ERDF funds (OP ERDF of Comunitat Valenciana 2014-2020). Special Research Actions from University of Valencia (REF: UV-INV-AE-1546096).

Data Availability All data generated or analysed during this study are included in this published article.

\section{Declarations}

Ethics Approval All procedures were performed in accordance to the protocols approved by 'Comisión de Ética en la Investigación Experimental, Vicerectorado de Investigación' of the University of Valencia (ref: A1510738650191, A1550947177828).

Consent to Participate Not applicable.

Consent for Publication All authors have seen and approved the manuscript and contributed significantly to this work.

Competing Interests The authors declare no competing interests.

Open Access This article is licensed under a Creative Commons Attribution 4.0 International License, which permits use, sharing, adaptation, distribution and reproduction in any medium or format, as long as you give appropriate credit to the original author(s) and the source, provide a link to the Creative Commons licence, and indicate if changes were made. The images or other third party material in this article are included in the article's Creative Commons licence, unless indicated otherwise in a credit line to the material. If material is not included in the article's Creative Commons licence and your intended use is not permitted by statutory regulation or exceeds the permitted use, you will need to obtain permission directly from the copyright holder. To view a copy of this licence, visit http://creativecommons.org/licenses/by/4.0/.

\section{References}

1. Alvarez-Buylla A, Garcia-Verdugo JM (2002) Neurogenesis in adult subventricular zone. J Neurosci 22(3):629-634

2. Christian KM, Song H, Ming GL (2014) Functions and dysfunctions of adult hippocampal neurogenesis. Annu Rev Neurosci 37:243-262

3. Fares J, Bou Diab Z, Nabha S, Fares Y (2019) Neurogenesis in the adult hippocampus: history, regulation, and prospective roles. Int J Neurosci 129(6):598-611

4. Obernier K, Alvarez-Buylla A (2019) Neural stem cells: origin, heterogeneity and regulation in the adult mammalian brain. Development. 146(4): dev156059.

5. Doetsch F, Petreanu L, Caille I, Garcia-Verdugo JM, AlvarezBuylla A (2002) EGF converts transit-amplifying neurogenic precursors in the adult brain into multipotent stem cells. Neuron 36(6):1021-1034

6. Doetsch F, García-Verdugo JM, Alvarez-Buylla A (1997) Cellular composition and three-dimensional organization of the subventricular germinal zone in the adult mammalian brain. J Neurosci 17(13):5046-5061

7. Lois C, Alvarez-Buylla A (1994) Long-distance neuronal migration in the adult mammalian brain. Science 264(5162):1145-1148

8. Ernst A, Alkass K, Bernard S, Salehpour M, Perl S, Tisdale J et al (2014) Neurogenesis in the striatum of the adult human brain. Cell 156(5):1072-1083

9. García-González D, Dumitru I, Zuccotti A, Yen TY, HerranzPérez V, Tan, LL, et al (2020) Neurogenesis of medium spiny neurons in the nucleus accumbens continues into adulthood and is enhanced by pathological pain. Mol Psychiatry 26(9):4616-4632

10. Sohn J, Orosco L, Guo F, Chung SH, Bannerman P, Ko EM et al (2015) The subventricular zone continues to generate corpus callosum and rostral migratory stream astroglia in normal adult mice. J Neurosci 35(9):3756-3763

11. Muñoz-Espín D, Serrano M (2014) Cellular senescence: from physiology to pathology. Nat Rev Mol Cell Biol 15:482-496

12. Dimri GP, Campisi J (1994) Molecular and cell biology of replicative senescence. Cold Spring Harb Symp Quant Biol 59:67-73

13. Kurz DJ, Decary S, Hong Y, Erusalimsky JD (2000) Senescenceassociated $\beta$-galactosidase reflects an increase in lysosomal mass during replicative ageing of human endothelial cells. J Cell Sci 113(20):3613-3622

14. Becker RE, Greig NH, Giacobini E (2008) Why do so many drugs for Alzheimer's disease fail in development? Time for new methods and new practices? J Alzheimers Dis 15:303-325

15. Tobin MK, Musaraca K, Disouky A, Shetti A, Bheri A, Honer WG et al (2019) Human hippocampal neurogenesis persists in aged adults and Alzheimer's disease patients. Cell Stem Cell. 24(6):974-982e3

16. Haughey NJ, Nath A, Chan SL, Borchard AC, Rao MS, Mattson MP (2002) Disruption of neurogenesis by amyloid $\beta$-peptide, and perturbed neural progenitor cell homeostasis, in models of Alzheimer's disease. J Neurochem 83(6):1509-1524

17. He P, Shen $Y$ (2009) Interruption of $\beta$-catenin signaling reduces neurogenesis in Alzheimer's disease. J Neurosci 29(20):6545-6557

18. Rodríguez JJ, Jones VC, Verkhratsky A (2009) Impaired cell proliferation in the subventricular zone in an Alzheimer's disease model. NeuroReport 20(10):907-912

19. Tang J, Song M, Wang Y, Fan X, Xu H, Bai Y (2009) Noggin and BMP4 co-modulate adult hippocampal neurogenesis in the APPswe/PS1 $\triangle \mathrm{E} 9$ transgenic mouse model of Alzheimer's disease. Biochem Biophys Res Commun 385(3):341-345

20. Moreno-Jiménez EP, Flor-García M, Terreros-Roncal J, Rábano A, Cafini F, Pallas-Bazarra N et al (2019) Adult hippocampal neurogenesis is abundant in neurologically healthy subjects and drops sharply in patients with Alzheimer's disease. Nat Med 25(4):554-560

21. Sorrells SF, Paredes MF, Cebrian-Silla A, Sandoval K, Qi D, Kelley KW et al (2018) Human hippocampal neurogenesis drops sharply in children to undetectable levels in adults. Nature 555(7696):377-381

22. Teplow DB (2006) Preparation of amyloid $\beta$-protein for structural and functional studies. Methods Enzymol 413:20-33

23. ElAli A, Thériault P, Préfontaine P, Rivest S (2013) Mild chronic cerebral hypoperfusion induces neurovascular dysfunction, triggering peripheral beta-amyloid brain entry and aggregation. Acta Neuropathol Commun 1(1):75

24. Faucher P, Mons N, Micheau J, Louis C, Beracochea DJ (2016) Hippocampal injections of oligomeric amyloid $\beta$-peptide (1-42) 
induce selective working memory deficits and long-lasting alterations of ERK signaling pathway. Aging Neurosci 7:1-15

25. Harkany T, Ábrahám I, Timmerman W, Laskay G, Tóth B, Sasvári $\mathrm{M}$ et al (2000) $\beta$-Amyloid neurotoxicity is mediated by a glutamate-triggered excitotoxic cascade in rat nucleus basalis. Eur J Neurosci 12(8):2735-2745

26. Prediger RDS, Franco JL, Pandolfo P, Medeiros R, Duarte FS, Di Giunta G et al (2007) Differential susceptibility following $\beta$-amyloid peptide-(1-40) administration in C57BL/6 and Swiss albino mice: evidence for a dissociation between cognitive deficits and the glutathione system response. Behav Brain Res 177(2):205-213

27. Guo H, Aleyasin H, Howard SS, Dickinson BC, Lin VS, HaskewLayton RE et al (2013) Two-photon fluorescence imaging of intracellular hydrogen peroxide with chemoselective fluorescent probes. J Biomed Opt 18(10):106002

28. Moser B, Hochreiter B, Herbst R, Schmid JA (2017) Fluorescence colocalization microscopy analysis can be improved by combining object-recognition with pixel-intensity-correlation. Biotechnol J. 12(1): 1600332

29. Wesson DW, Levy E, Nixon RA, Wilson DA (2010) Olfactory dysfunction correlates with amyloid-beta burden in an Alzheimer's disease mouse model. J Neurosci 30:505-514

30. Sundberg H, Doving K, Novikov S, Ursin H (1982) A method for studying responses and habituation to odors in rats. Behav Neural Biol 34:113-119

31. Burma S, Chen BP, Murphy M, Kurimasa A, Chen DJ (2001) ATM phosphorylates histone $\mathrm{H} 2 \mathrm{AX}$ in response to DNA doublestrand breaks. J Biol Chem 276(45):42462-42467

32. Kieroń M, Żekanowski C, Falk A, Wężyk M (2019) Oxidative DNA damage signalling in neural stem cells in Alzheimer's disease. Oxid Med Cell Longev 2019:2149812

33. Sedelnikova OA, Pilch DR, Redon C, Bonner WM (2003) Histone $\mathrm{H} 2 \mathrm{AX}$ in DNA damage and repair. Cancer Biol Ther 2:233-235

34. Myung NH, Zhu X, Kruman II, Castellani RJ, Petersen RB, Siedlak SL et al (2008) Evidence of DNA damage in Alzheimer disease: phosphorylation of histone $\mathrm{H} 2 \mathrm{AX}$ in astrocytes. Age 30(4):209-215

35. Lloret A, Badía MC, Mora NJ, Ortega A, Pallardó FV, Alonso MD et al (2008) Gender and age-dependent differences in the mitochondrial apoptogenic pathway in Alzheimer's disease. Free Radic Biol Med 44(12):2019-2025

36. He ZY, Wang WY, Hu WY, Yang L, Li Y, Zhang WY et al (2016) Gamma-H2AX upregulation caused by Wip1 deficiency increases depression-related cellular senescence in hippocampus. Sci Rep 6:34558

37. Hovest MG, Brüggenolte N, Hosseini KS, Krieg T (2006) Herrmann, G Senescence of human fibroblasts after psoralen photoactivation is mediated by ATR kinase and persistent DNA damage foci at telomeres. Mol Biol Cell 17(4):1758-1767

38. Pospelova TV, Demidenko ZN, Bukreeva EI, Pospelov VA, Gudkov AV (2009) Blagosklonny MV Pseudo-DNA damage response in senescent cells. Cell Cycle 8:4112-4118

39. Lim DA, Alvarez-buylla A (2016) The adult ventricular - subventricular zone. Cold Spring Harb Perspect Biol 8(5):a018820

40. Scopa C, Marrocco F, Latina V, Ruggeri F, Corvaglia V, La Regina $\mathrm{F}$ et al (2020) Impaired adult neurogenesis is an early event in Alzheimer's disease neurodegeneration, mediated by intracellular A $\beta$ oligomers. Cell Death Differ 27(3):934-948

41. da Cunha BR, Domingos C, Buzzo Stefanini AC, Henrique T, Polachini GM, Castelo-Branco P, Tajara EH (2019) Cellular interactions in the tumor microenvironment: the role of secretome. J Cancer 10:4574-4587

42. Rodier F, Campisi J (2011) Four faces of cellular senescence. J Cell Biol 192:547-556
43. Wilkinson HN, Hardman MJ (2020) Senescence in wound repair: emerging strategies to target chronic healing wounds. Front Cell Dev Biol 8:773

44. Kojima T, Hirota Y, Ema M, Takahashi S, Miyoshi I, Okano H, Sawamoto K (2010) Subventricular zone-derived neural progenitor cells migrate along a blood vessel scaffold toward the poststroke striatum. Stem Cells. 28(3): 545-554

45. de Boer HR, Guerrero Llobet S, van Vugt MA (2016) Controlling the response to DNA damage by the APC/C-Cdh1. Cell Mol Life Sci 73(5):949-960

46. Ha K, Ma C, Lin H, Tang L, Lian Z, Zhao F et al (2017) The anaphase promoting complex impacts repair choice by protecting ubiquitin signalling at DNA damage sites. Nat Commun $8(1): 15751$

47. Lara-Gonzalez P, Kim T, Desai A (2017) Taming the beast: control of APC/CCdc20-dependent destruction. Cold Spring Harb Symp Quant Biol 82:111-121

48. Takahashi A, Imai Y, Yamakoshi K, Kuninaka S, Ohtani N, Yoshimoto $\mathrm{S}$ et al (2012) DNA damage signaling triggers degradation of histone methyltransferases through APC/C Cdh1 in senescent cells. Mol Cell 45(1):123-131

49. Feringa FM, Krenning L, Koch A, Van Den Berg J, Van Den Broek B, Jalink K, Medema RH (2016) Hypersensitivity to DNA damage in antephase as a safeguard for genome stability. Nat Commun 7:12618

50. Zhang J, Li H, Zhou T, Zhou J, Herrup K (2012) Cdk5 levels oscillate during the neuronal cell cycle: Cdh1 ubiquitination triggers proteosome-dependent degradation during S-phase. J Biol Chem 287(31):25985-25994

51. Almeida A, Bolaños JP, Moreno S (2005) Cdh1/Hct1-APC is essential for the survival of postmitotic neurons. J Neurosci 25(36):8115-8121

52. Maestre C, Delgado-Esteban M, Gomez-Sanchez JC, Bolaños JP, Almeida A (2008) Cdk5 phosphorylates Cdh1 and modulates cyclin B1 stability in excitotoxicity. EMBO J 27(20):2736-2745

53. Ayala R, Shu T, Tsai L-H (2007) Trekking across the brain: the journey of neuronal migration. Cell 128(1):29-43

54. Schneider L, Pellegatta S, Favaro R, Pisati F, Roncaglia P, Testa G et al (2013) DNA damage in mammalian neural stem cells leads to astrocytic differentiation mediated by BMP2 signaling through JAK-STAT. Stem Cell Rep 1(2):123-138

55. Schneider L (2014) Survival of neural stem cells undergoing dna damage-induced astrocytic differentiation in self-renewalpromoting conditions in vitro. PLoS ONE 9(1):e87228

56. Zhan JS, Gao K, Chai RC, Jia XH, Luo DP, Ge G et al (2017) Astrocytes in migration. Neurochem Res 42(1):272-282

57. Devanand DP, Michaels-Marston KS, Liu X, Pelton GH, Padilla M, Marder K et al (2000) Olfactory deficits in patients with mild cognitive impairment predict Alzheimer's disease at follow-up. Am J Psychiatry 157(9):1399-1405

58. Velayudhan L, Pritchard M, Powell JF, Proitsi P, Lovestone S (2013) Smell identification function as a severity and progression marker in Alzheimer's disease. Int Psychogeriatr 25(7):1157-1166

59. Yu Q, Guo P, Li D, Zuo L, Lian T, Yu S et al (2018) Olfactory dysfunction and its relationship with clinical symptoms of Alzheimer disease. Aging Dis 9(6):1084-1095

60. Wang C, Liu F, Liu Y-Y, Zhao C-H, You Y, Wang L et al (2011) Identification and characterization of neuroblasts in the subventricular zone and rostral migratory stream of the adult human brain. Cell Res 21(11):1534-1550

61. Ardekani BA, Bachman AH, Figarsky K, Sidtis JJ (2014) Corpus callosum shape changes in early Alzheimer's disease: an MRI study using the OASIS brain database. Brain Struct Funct 219(1):343-352 
62. Benedicte M, Garcia-Verdugo JM, Yaschine C, Gonzalez-Perez O, Rowitch D, Alvarez-Buylla A (2006) Origin of oligodendrocytes in the subventricular zone of the adult brain. J Neurosci 26:7907-7918

63. Mizrak D, Levitin HM, Delgado AC, Crotet V, Yuan J, Chaker Z et al (2019) Single-cell analysis of regional differences in adult V-SVZ neural stem cell lineages. Cell Rep 26(2):394-406e5

64. Selden N, Mesulam MM, Geula C (1994) Human striatum: the distribution of neurofibrillary tangles in Alzheimer's disease. Brain Res 648(2):327-331

65. Pulakat L, Chen HH (2020) Pro-senescence and anti-senescence mechanisms of cardiovascular aging: cardiac MicroRNA regulation of longevity drug-induced autophagy. Front Pharmacol $11: 774$
66. Rodríguez-Matellán A, Alcazar N, Hernández F, Serrano M, Ávila J (2020) In vivo reprogramming ameliorates aging features in dentate gyrus cells and improves memory in mice. Stem Cell Rep 15(5):1056-1066

67. Zhang P, Kishimoto Y, Grammatikakis I, Gottimukkala K, Cutler RG, Zhang S et al (2019) Senolytic therapy alleviates $\mathrm{A} \beta$-associated oligodendrocyte progenitor cell senescence and cognitive deficits in an Alzheimer's disease model. Nat Neurosci 22(5):719-728

Publisher's Note Springer Nature remains neutral with regard to jurisdictional claims in published maps and institutional affiliations. 